\title{
OD REDAKTORÓW
}

Od kilku dekad obserwujemy w humanistyce wzmożone zainteresowanie przeszłością, zwłaszcza tą będącą udziałem pokoleń poprzedzających nasze narodzenie. Nie byłoby w tym nic dziwnego, przecież historia jest jedną z najstarszych nauk, a zainteresowanie jednostek tym, co wydarzyło się przed ich pojawieniem się na świecie, wydaje się odwieczne i naturalne. Jednak te zagadnienia, w potocznym odbiorze zarezerwowane właśnie dla historyków, poruszane są ostatnio przez badaczy reprezentujących różne dyscypliny: kulturoznawców, filozofów, literaturoznawców, socjologów, psychologów, historyków, politologów, historyków sztuki, filmoznawców, teatrologów... Jest to nurt na tyle znaczący i wyrazisty, że mówi się wprost o kolejnym - po lingwistycznym, kulturowym, ikonicznym, historiograficznym, topograficznym, performatywnym - zwrocie we współczesnych naukach humanistycznych, zwrocie pamięciowym.

Można zastanawiać się, dlaczego pamięć i jej odmiany stanęły dziś w centrum zainteresowań badawczych humanistów. Czy może mamy do czynienia z jakąś szczególną modą we współczesnej nauce? Wydaje się, że refleksja nad różnymi przejawami pamięci nie jest zjawiskiem oderwanym od rzeczywistości, lecz raczej konsekwencją tego, co dzieje się w świadomości społecznej i znajduje swoje odzwierciedlenie m.in. w różnego rodzaju formach aktywności obywatelskiej (takiej jak np. rekonstruowanie losów dawnych społeczności lokalnych) i w różnych dziedzinach sztuki.

Artykuły zgromadzone w numerze Politei, który oddajemy do rąk czytelników, zostały napisane przez autorów uprawiających różne dyscypliny naukowe, łączy je jednak skupienie na szczególnym rodzaju pamięci, tzw. postpamięci. Termin ten został zapożyczony z prac Marianne Hirsch i jest stosowany, by wyodrębnić specyficzną pamięć drugiego - bądź kolejnego - pokolenia, dziedziczącego traumę, która stała się udziałem generacji poprzedniej. Przypomnijmy, że pochodząca z Rumunii badaczka stworzyła je, by opisać swoistość doświadczenia potomków osób ocalałych z Zagłady. Ci, którzy przeżyli, przekazali swoim dzieciom, świadomie lub nie, pamięć o potwornościach, które przeszli. Ten cień tragicznej przeszłości trwale wpisał się w biografię członków kolejnego pokolenia, stając się niezbywalnym elementem ich tożsamości. 
W ostatnich latach powstało wiele prac opisujących doświadczenia generacji, która odziedziczyła traumę po swoich przodkach. Niektórzy uczeni, w zależności od zastosowanych narzędzi badawczych, nierzadko odwołując się do własnych przeżyć i wspomnień, posługują się innymi terminami, by opisać to zjawisko. I tak np. Nadine Fresco pisała o pamięci nieobecnej (mémoire absente), zgłębiając sytuację osób, których rodzice nie chcieli lub nie byli w stanie rozmawiać o traumach przeszłości, więc docierające do nich informacje o niej były z konieczności wybiórcze i niepełne. Henri Raczymow mówił o pamięci podziurawionej (mémoire trouée). James E. Young wolał określenie „pamięć zastępcza” (vicarious past). Powstały także prace negujące zasadność wyodrębniania tego rodzaju pamięci.

Jakkolwiek jesteśmy świadomi wielości terminów opisujących doświadczenie traumy odziedziczonej, a także krytyki nurtu postpamięciowego, postanowiliśmy pozostać przy terminologii zaproponowanej przez Marianne Hirsch. Z jednej strony, termin „postpamięćc" zadomowił się w humanistyce i jest łatwo rozpoznawalny. Z drugiej strony, jest użyteczny, ponieważ jednoznacznie zakreśla pole badawcze. Po pierwsze, w odróżnieniu od pamięci tout court, która odnosi się przede wszystkim do wspomnień dotyczących bezpośredniego doświadczenia, postpamięć opisuje wiedzę o wydarzeniach i przeżyciach nabytą od innych - uczestników lub świadków dawnych wypadków. Po drugie, zawsze dotyczy doświadczeń traumatycznych, podczas gdy „zwykła” pamięć obejmuje wspomnienia zarówno negatywne, jak i pozytywne.

Sama Marianne Hirsch sugerowała, że zjawisko postpamięci nie jest udziałem wyłącznie potomków ofiar Zagłady, i uznała, iż termin ten może być stosowany również, gdy chcemy opisać doświadczenia dzieci tych, dla których jakikolwiek system totalitarny stanowił przeżycie pokoleniowe. Idąc tropem myśli Hirsch, nie zawężamy pola zainteresowań do problematyki związanej z Zagładą, ale przedstawiamy także teksty poruszające obecność innych doświadczeń związanych z II wojną światową w narracjach kolejnych pokoleń oraz artykuły analizujące zjawisko postpamięci w kontekstach pozaeuropejskich.

Mamy nadzieję, że prezentacja różnych podejść badawczych do zjawiska postpamięci i różnych sposobów opisu jej przejawów okaże się interesująca dla wszystkich zainteresowanych problematyką manifestacji przeszłości we współczesnej kulturze. 